\title{
Does Wine Quality Have a Bearing on Exports?
}

Anthony Macedo, Sofia Gouveia, João Rebelo

Department of Economics, Sociology and Management, Centre for Transdisciplinary Development Studies, University of Trás-os-Montes and Alto Douro, Vila Real, Portugal

\begin{abstract}
This study examines the macroeconomic determinants of exports, taking quality into account through vertical differentiation and using data on Portuguese Douro wines. Based on a gravity model from 2006 to 2015 and covering a range of 192 potential trade partners, estimations show that quality influences export performance. However, quality differences are not assimilated in the same way in all international markets, resulting in an export surplus of the best categories of wine to some world regions (West Europe and AngloSaxon countries) and a correspondingly export deficit to other regions (Middle East, North Africa, East Europe and Central Asia).
\end{abstract}

JEL classification codes: F14; L15; L66

\section{Keywords}

Vertical differentiation; Market segmentation; Gravity model; Douro wine.

Macedo, A., Gouveia, S. and Rebelo, J. (2019) "Does Wine Quality Have a Bearing on Exports?", AGRIS on-line Papers in Economics and Informatics, Vol. 11, No. 4 pp. 49-59. ISSN 1804-1930. DOI 10.7160/aol.2019.110405.

\section{Introduction}

In today's globalized world, the economic performance of a country is closely related to the world market competitiveness of its key products. Wine is a typical product of globalization for which international trade started to increase significantly in the 1970s (Castillo et al., 2016) but has recently undergone a slowdown of growth (Pomarici, 2016). Since the 1970s, new exporting countries have emerged and demand for wine has flourished worldwide, which has in turn, led to diversification of the product, changes in consumption patterns and increasing competition between players at an international level.

Therefore, having an understanding of the determinants of exports is crucial in the decision-making process of stakeholders. Much of the debate over the factors influencing international trade centres on the gravity model formulated by Tinbergen (1962) and later enriched by the contributions of Anderson (1979), Helpman (1984, 1987), Helpman and Krugman (1985), Bergstrand (1985, 1989), Eaton and Kortum (2002), Anderson and van Wincoop (2003), and Silva and Tenreyro (2006), among others. From this perspective, there is a substantial amount of literature focusing on the determinants of the international wine trade (Dascal et al., 2002; Castillo et al., 2016; Dal Bianco et al., 2016; Lombardi et al., 2016; Balogh and Jámbor, 2018). However, most attention has been focused on horizontal differentiation while the influence of vertical differentiation on wine exports has not been the subject of so much interest, despite the recognition that quality differentials exist in the wine industry (Cardebat and Figuet, 2004) ${ }^{1}$. Some studies (e.g., Schamel, 2006; Brentari et al., 2011) explore this perspective estimating the hedonic price function to support the idea that wines with geographical indications (horizontal differentiation) benefit from collective reputation because they are commonly perceived as guarantees of quality for which consumers are willing to pay more. Other approaches attempting to study

\footnotetext{
${ }^{1}$ Comparing different varieties of a product equally priced, there is horizontal differentiation if consumers have heterogeneous preferences regarding the most preferred mix of different attributes. If, on the contrary, most of the consumers unanimously agree on a quality index then the product is vertically differentiated (Church and Ware, 2000). Wine is a product horizontally differentiated in the sense that consumers do not have the same willingness to pay for some attributes (e.g., colour, alcohol content, place of origin or grape varietal composition), but it is also vertically differentiated in the sense that these attributes can together generate quality differentials, usually reflected in the prices (Boccard, 2010).
} 
the impact of quality on wine exports are presented by Agostino and Trivieri $(2014,2016)$ and Crozet et al. (2012), the former using the gravity model to estimate an export surplus for the wines of France, Spain and Italy with geographical indications, and the latter matching firm-level export data with expert assessments of quality to suggest that, for champagne producers, quality increases firm-level prices, the probability of market entry, and export values.

This study aims to contribute to the debate on the impact of quality on international trade by means of testing if an increment of quality within a Protected Designation of Origin (PDO) generates an export surplus. Additionally, it is also a goal of this study to determine whether quality differences are homogeneously interpreted across world regions. To do this, PDO Douro wine (henceforth Douro wine) is used as an example of a differentiated product with recent success in international markets. Considering 192 partner countries divided into nine world regions, an expanded gravity equation for the period 2006-2015 is estimated through Bonus Vetus OLS (BVOLS). This estimator allows for repeated time values within the panel, as well as controlling for multilateral resistance (MR) terms.

The contribution of this paper is threefold. First, it provides a new perspective to the debate about the relationship between quality and international trade by considering the exports of different categories within a PDO. Second, this study brings to the discussion the role of market segmentation in highly competitive markets and how quality is apprehended by distinct world regions. Third, this paper presents a different methodology from most of the wine trade literature (recently inclined to the Poisson pseudo-maximum likelihood) whilst fitting in well with the question under study, as BVOLS is an estimator capable of considering the trade flows of several categories between two trade partners in each year, while controlling for MR terms.

The rest of the paper is organized as follows. The section Material and Methods provides an overview of the literature about the relationship between product quality and international trade, describes the empirical approach and present the data. The section Results and Discussion shows and analyses the results. Finally, the section Conclusion summarizes the main findings.

\section{Materials and methods}

\section{Product quality and international trade: an overview}

Product quality was introduced to the literature on international trade by the seminal work of Linder (1961), where it was proposed that higher quality products are more likely to be traded between rich countries and the more similar the demand structures of countries, the more they will trade with one another. Since then, the relationship between product quality and trade has been the subject of research using different approaches, which can be divided into two main strands: one studying the attributes of exporting and importing countries (e.g., Hummels and Skiba, 2004; Schott, 2004; Hummels and Klenow, 2005; Khandelwal, 2010; Agostino and Trivieri, 2014); and the other, inspired by the seminal paper of Melitz (2003), exploring models with firms heterogeneity and firm-level data (e.g., Verhoogen, 2008; Crozet et al., 2012; Manova and Zhang, 2012).

Among the first strand, Hummels and Skiba (2004) generalize the Alchian and Allen's (1972) conjecture $^{2}$ and show empirically that the relative price of high-quality products decreases when transaction cost is applied per unit, which leads to a positive co-variation between high quality and transaction costs. Schott (2004), Hummels and Klenow (2005) and Khandelwal (2010) suggest that quality increase along with higher per capita income of exporting countries due to endowment advantage can, in turn, be used to add further quality to products. Additionally, Hummels and Klenow (2005) highlight the relevance of quality by estimating that a 9 percent difference in real income per worker between countries may ultimately be a reflection of differences in quality between those countries. The study of Khandelwal (2010) has the particularity of inferring quality based on value and quantity information, following the intuition that, conditional on price, higher quality is assigned to products with higher market shares. The author also states that it is misleading to use price alone as a proxy of quality since price also reflects production costs. Agostino and Trivieri (2014), using a gravity equation for wine exports of France, Italy and Spain, find there is a positive pay-off for quality wines produced in specified regions (QWPSR) in terms of greater export value

\footnotetext{
${ }^{2}$ Due to transportation costs, goods of higher quality are exported, while the ones with lower quality are for domestic consumption.
} 
compared to all other still wines ${ }^{3}$. They conclude that, despite this designation generating additional costs of compliance, it produces benefit from collective reputation, which acts as a certification of quality.

In the second strand of the literature, Verhoogen (2008) investigates Mexican manufacturing plants and argues that an increase in exports leads to wage inequality through quality upgrading ${ }^{4}$. The study of Manova and Zhang (2012) using data on Chinese trading firms concludes that trade reforms may lead firms to vary product quality within and across markets $^{5}$. Ultimately, a common limitation of this strand of the literature is the difficulty in quantifying quality and Crozet et al. (2012) solve this by using experts' ratings for champagne producers, which lead to the finding that an improvement in quality increases not only firm-level prices, but also the probability of market entry, as well as export values.

\section{The gravity equation of wine exports}

In the literature, gravity models have established themselves as key tools for the analysis of international trade. This is also true for wine trade studies, which have highlighted the influence on trade between two countries of factors such as gross domestic product (GDP) per capita, distance, contiguity, common language, common currency and trade agreements (e.g. Dascal et al., 2002; Olper et al., 2012; Castillo et al., 2016; Dal Bianco et al., 2016; Lombardi et al., 2016; Dal Bianco et al., 2017; Gouveia et al., 2018). GDP per capita represents purchasing power, therefore it is expected that countries with higher purchasing power should import more Douro wine as happens with other wines (e.g., Dascal et al., 2002; Gouveia et al., 2018). Distance between trade partners is a common proxy variable for transport costs and has a negative impact on trade in several

\footnotetext{
${ }^{3}$ Agostino and Trivieri (2016) corroborate with this result providing also empirical evidence on the performance of geographically designated and indicated wines in emerging economies.

${ }^{4}$ In the model of Verhoogen (2008) with heterogeneous plants and quality differentiation, more productive plants produce higherquality goods than less productive plants, and they pay higher wages to maintain a higher-quality workforce. Only the most productive plants enter the export market, so if there is any bilateral reduction in trade costs (e.g., trade agreement, declining transport cost or exchange-rate devaluation) it will increase the differential in the export share as well as the within industry differentials in quality and, consequently, wages.

5 The research of Manova and Zhang (2012) has two main implications: i) successful exporters have products of better quality because they use higher-quality inputs, and; ii) by using different levels of quality in inputs, firms can export products with different quality across destinations.
}

studies (e.g., Castillo et al., 2016; Dal Bianco et al., 2016, 2017; Lombardi et al., 2016). Cultural and historical proximity can benefit the trade relationship between two countries and contiguity and common language are two typical proxies for it; the positive impact of sharing the same language on wine trade having been proved in some studies (e.g. Castillo et al., 2016; Dal Bianco et al., 2016; Lombardi et al., 2016; Gouveia et al., 2018). Trade agreements, generally, are designed to create better trading opportunities and reduce costs, thus, such an agreement being established between two countries is expected to enhance trade. In wine trade literature, it is common to test the effect on trade of two trade partners being members of specific regional trade agreements (e.g., Dascal et al., 2002; Castillo et al., 2016) and/or sharing the same currency (e.g., Agostino and Trivieri, 2014, 2016; Castillo et al., 2016).

To identify the main factors influencing Douro wine exports, the following gravity equation is estimated with continuous variables log-transformed:

$$
\begin{aligned}
& \ln \text { exports }_{i j k t}=\beta_{0}+\beta_{1} \ln \text { gdppc }_{j t}+\beta_{2} \ln \text { dist }_{i j} \\
& \quad+\beta_{3} \text { lang }_{i j}+\beta_{4} \text { curr }_{i j t}+\beta_{5} \text { rta }_{i j t}+\beta_{6} \text { cont }_{i j} \\
& \quad+\beta_{7} \text { reserve }_{k t}+\beta_{8} \text { grand }_{k t}+\sum_{t} \gamma_{t} T_{t}+u_{i j t}
\end{aligned}
$$

Equation (1) is based on Agostino and Trivieri (2014, 2016), so that the main difference in this work is that the dependent variable exports ${ }_{i j k t}$ stands only for the exports of one country $i$ (Portugal) to several countries $j$ over time $t$. Another particularity of this model is that $k$ distinguishes three qualities of Douro wine, but all with PDO: standard, reserve and grand reserve. Regarding the explanatory variables: $g d p p c$ is the GDP per capita of the importing country; dist is the distance between exporting and importing countries; lang is equal to 1 if the official language is common to both trade partners, and 0 otherwise; curr is 1 if the same currency is shared by both trade partners, and 0 otherwise; rta is 1 if both trade partners are members of the same RTA, and 0 otherwise; cont is 1 if there is contiguity between the importer and the exporter, and 0 otherwise; reserve is equal to 1 if the export flow of line $k$ and time $t$ is a wine with reserve category; grand is equal to 1 if the export flow of line $k$ and time $t$ is a wine with grand reserve category. Finally, a set of time fixed effects is considered through $T$ and $u$ is the error term.

Regarding the econometric methodology, the BVOLS is used following Baier and Bergstrand (2009). Based upon the model of Anderson 
and van Wincoop (2003), trade between countries $i$ and $j$ is not only determined by their own trade barriers, but also by the relative trade costs of these countries with the rest-of-the-world. Baier and Bergstrand (2009) introduce these theoreticallymotivated exogenous multilateral resistance terms in a simple reduced-form gravity equation that can be estimated with OLS. This estimator seems to be the most appropriate for this study because, besides controlling for MR terms, it allows for repeated time values within a panel, that is, it can consider the three export flows in the study (standard, reserve and grand reserve Douro wines) between Portugal and its trade partners in each year $t$. To approximate MR terms, Baier and Bergstrand (2009) suggest a first-order log-linear Taylor-series expansion of the system of nonlinear price equations terms in Anderson and van Wincoop (2003), as follows:

$$
\begin{aligned}
M R X_{i j} & =\sum_{k=1}^{N_{k}}\left(\frac{G D P_{k}}{G D P_{w}} X_{i k}\right)+\sum_{m=1}^{N_{m}}\left(\frac{G D P_{m}}{G D P_{w}} X_{m j}\right) \\
& -\sum_{k=1}^{N_{k}} \sum_{m=1}^{N_{m}}\left(\frac{G D P_{k}}{G D P_{w}} \frac{G D P_{m}}{G D P_{w}} X_{k m}\right)
\end{aligned}
$$

where $X$ are proxies of bilateral trade costs and $k$ and $m$ are trade partners of $i$ and $j$, respectively. Therefore, the gravity equation (1) can be estimated through OLS if dist, lang, curr, rta and cont are transformed by subtracting the exogenous terms (2).

\section{Data}

In order to estimate the determinants of wine exports and the impact of quality, this paper considers the Douro wine as an example. Douro wine is produced in the Demarcated Douro Region (DDR) which fits the typical terroir model and is the largest and the most heterogeneous wine mountain region in the world (Rebelo and Muhr, 2012). Different from Port wine, also produced in the DDR and with more than two centuries of having been sold in external markets, Douro wine started to leave its mark on international markets only at the beginning of the $21^{\text {st }}$ century (which explains why there is no record of exports before 2006). From 2006 to 2015 , exports have grown rapidly at an average annual rate of $12 \%$ and $10 \%$ in value and volume, respectively. A contributory factor to this success has been a strategy of searching for market niches and focusing on differentiation through product and process innovation, and marketing (Rebelo and Muhr, 2012).

The Port and Douro Wines Institute (IVDP) is the regulator responsible for the quality control of Douro wine, recognizing three main categories with the following ascending order of quality: standard, reserve and grand reserve (see Gouveia and Macedo, 2017). The regulator assigns wines into these respective categories by organoleptic evaluation and sensorial analysis through expert wine tasting (Regulations n. ${ }^{\circ}$ 242/2010 and n. ${ }^{\circ} 82 / 2010$, IVDP).

Figure 1 shows the continuous growth of total Douro wine exports in value between 2006 and 2015 . The standard category exports remained stable until 2010. However, in the following five years they more than doubled. Regarding the evolution of exports of the reserve and grand reserve categories, these have been positive since 2006:

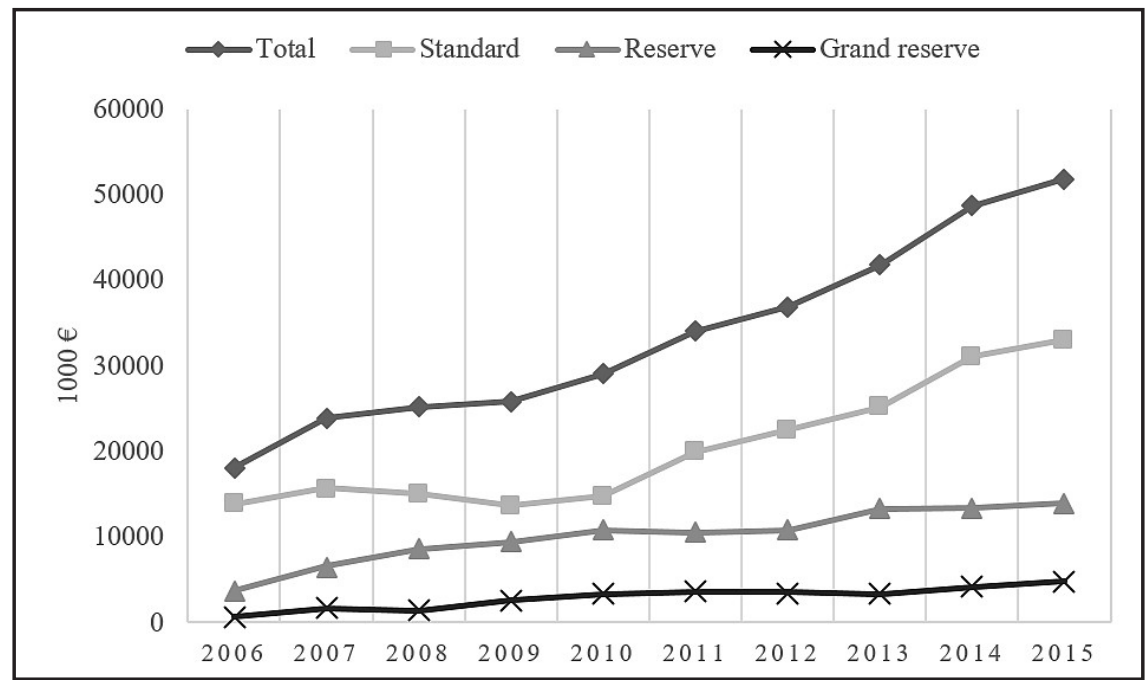

Source: Own computation based on IVDP data (www.ivdp.pt)

Figure 1: Evolution of Douro wine exports by category, in value, 2006-2015. 
the average annual rates of growth being $16 \%$ and $25 \%$, both of which are higher than for the standard category $(10 \%)$. This has led to a growing awareness of the importance of the reserve and grand reserve categories. From 2006 to 2015, their shares in total Douro wine exports increased 6 percentage points each.

The main destinations of Douro wine exports are most high-income countries (e.g. Belgium, Canada, France, Germany, Poland, Switzerland, United Kingdom and United States of America), economies with advanced development (Brazil and China) or former Portuguese colonies (Angola and Macao). In Table 1 it can be observed that most of the main importing countries are common for each Douro wine category, despite presenting a different order. The ten main importers of Douro wine represented $80 \%$ of total exports in value (in volume the share was $81 \%$ ) in 2015 (in 2006 it was $82 \%$ in value). This means that Douro wine exports have a high level of concentration toward a small number of destinations, which is also a sign of dependence on these markets.

Data on exports of bottled Douro wine was extracted in value (euro) and volume (litres) from the website of IVDP, while all the data for GDP per capita, distance, language, RTA's, common currency and contiguity was collected from the CEPII Gravity Dataset (descriptive statistics of all the variables are presented in Table A1 of Appendix). GDP per capita from the CEPII dataset is presented in US dollars, so a conversion to euro is done using the official exchange rates from World Bank's dataset World Development Indicators. The distance between trade partners is based on bilateral distance between the biggest cities of those countries and weighted by the share of population of that city in terms of the country's overall population.

The dataset used in the next section covers 192 partner countries over the period 2006-2015 $5^{6}$. Around $65 \%$ of the export flows are zeros, which leads to the loss of several observations due to the undefined logarithm of zero. Therefore, adding a constant of 1 to the value/volume of exports before transforming them into log form allows for an increase in the number of observations.

\section{Results and discussion}

Table 2 presents the results estimated for the exports of Douro wine, in value and volume. Columns (1) and (3) refer to estimations using as dependent variables the log form of exports in euro and litres, respectively, while in columns (2) and (4) a constant of 1 is added to exports before transforming them into $\log$ form. In order to achieve robust standard errors, i.e. heteroscedasticity consistent, and to allow for the correlation of the idiosyncratic error terms of the same country-pairs over time, the models are estimated considering clusters at the country-pair level (Agostino and Trivieri, 2014, 2016). Moreover, the graphical analysis of the distribution of residuals suggests that there are no problems of normality (see the Figure A1 of Appendix). In addition, time effects were globally

\footnotetext{
${ }^{6}$ Only 5589 of 5760 potential observations (= 192 countries, * 10 years, * 3 categories of wine), are available for estimations because of missing data in CEPII dataset.
}

\begin{tabular}{|c|l|c|c|l|c|c|l|c|c|l|c|c|}
\hline & \multicolumn{3}{|c|}{ Total Douro } & \multicolumn{3}{c|}{ Standard (64\%) } & \multicolumn{3}{c|}{ Reserve (27\%) } & \multicolumn{3}{c|}{ Grand Reserve (9\%) } \\
\cline { 2 - 13 } & Country & $\mathbf{1 0 0 0} €$ & $\mathbf{\%}$ & Country & $\mathbf{1 0 0 0} €$ & $\mathbf{\%}$ & Country & $\mathbf{1 0 0 0} €$ & $\mathbf{\%}$ & Country & $\mathbf{1 0 0 0} €$ & $\mathbf{\%}$ \\
\hline 1 & Canada & 7666 & 15 & Canada & 5977 & 18 & Switz. & 1826 & 13 & USA & 663 & 14 \\
\hline 2 & Angola & 5627 & 11 & Angola & 3630 & 11 & USA & 1615 & 12 & Brazil & 637 & 13 \\
\hline 3 & USA & 5513 & 11 & Brazil & 3319 & 10 & Angola & 1496 & 11 & Switz. & 576 & 12 \\
\hline 4 & Brazil & 5037 & 10 & USA & 3234 & 10 & Canada & 1465 & 10 & Angola & 500 & 10 \\
\hline 5 & Switz. & 4815 & 9 & Germany & 2752 & 8 & UK & 1157 & 8 & Germany & 276 & 6 \\
\hline 6 & Germany & 3856 & 7 & Switz. & 2409 & 7 & Brazil & 1078 & 8 & Macao & 273 & 6 \\
\hline 7 & UK & 3142 & 6 & UK & 1751 & 5 & Germany & 827 & 6 & China & 252 & 5 \\
\hline 8 & France & 2390 & 5 & France & 1705 & 5 & Belgium & 599 & 4 & UK & 231 & 5 \\
\hline 9 & Belgium & 2166 & 4 & Belgium & 1409 & 4 & France & 544 & 4 & Canada & 223 & 5 \\
\hline 10 & China & 1270 & 2 & Poland & 1058 & 3 & China & 462 & 3 & Belgium & 158 & 3 \\
\hline & Top 10 & 41481 & 80 & Top 10 & 27243 & 82 & Top 10 & 11069 & 79 & Top 10 & 3932 & 81 \\
\hline & World & 51865 & 100 & World & 33033 & 100 & World & 13978 & 100 & World & 4827 & 100 \\
\hline
\end{tabular}

Notes: Switz.= Switzerland; UK = United Kingdom; USA = United States of America

Source: IVDP (www.ivdp.pt)

Table 1: Top 10 destinations of Douro wine exports, by category, in 2015. 
significant in (2) and (4) and therefore included in all regressions via dummy variables for each year, but have been omitted due to space considerations.

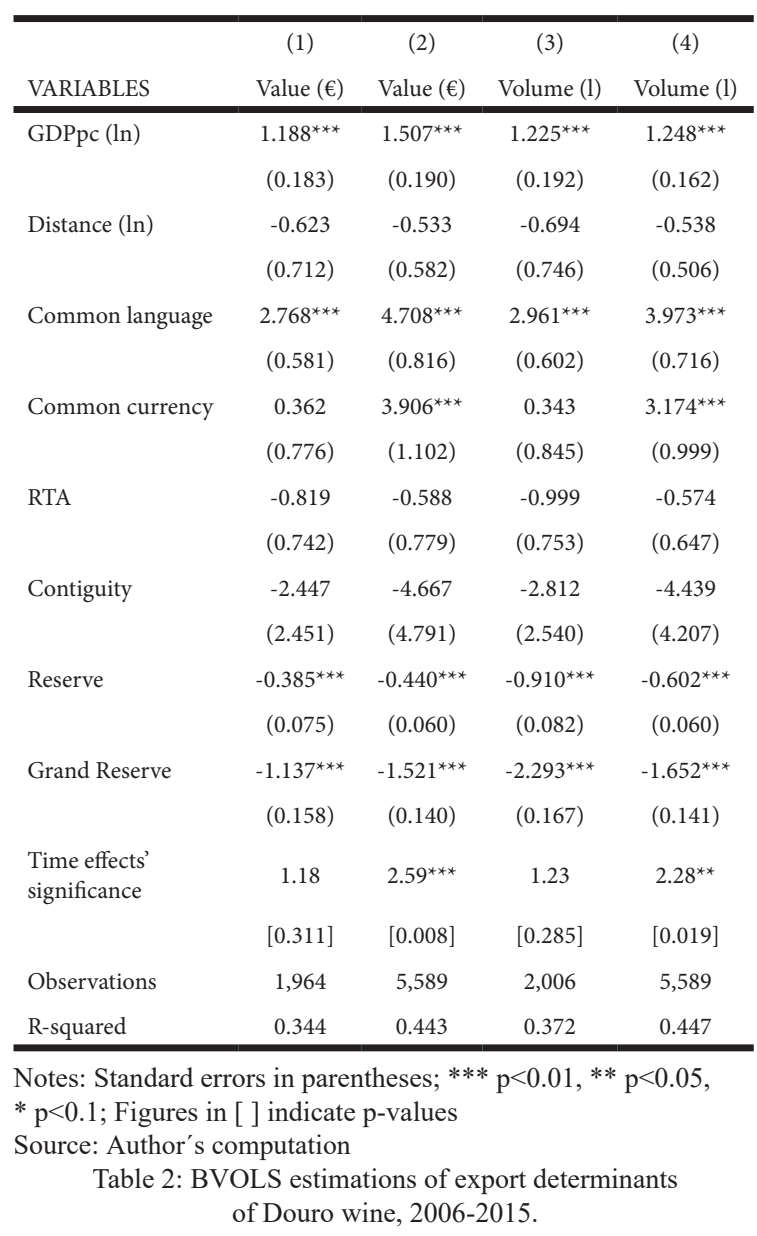

The results suggest the expected sign for gravity variables in value and volume ${ }^{7}$. Columns (2) and (4) present higher $R^{2}$ than columns (1) and (3), suggesting some benefits of using more observations in estimations. Nevertheless, the results are similar and the main exception is the statistically significant effect of common currency when the number of observations is higher. Common currency is a facilitator of trade and its positive effect was already highlighted by Agostino and Trivieri (2014, 2016).

GDP per capita has a positive and statistically significant impact on Douro wine exports, so that countries with higher income per capita display a greater ability to import Douro wine ${ }^{8}$. This is consistent with the results of other studies employing the gravity model to investigate

\footnotetext{
${ }^{7}$ Contiguity and RTA present unexpected negative signs. They are however, without statistical significance.

${ }^{8}$ Income elasticity being higher than one indicates that Douro wine exports share some characteristics of luxury goods.
}

the determinants of the wine trade (Dascal et al., 2002; Dal Bianco et al., 2016, 2017).

The positive effect of common language on exports is in line with other works (Castillo et al., 2016; Dal Bianco et al., 2017) and this effect fits Portuguese wine well because Portugal maintains a good commercial relationship with former colonies such as Angola ${ }^{9}$, Brazil and Mozambique. Remaining gravity variables do not have statistically significant effects on exports.

The effect of quality on Douro wine exports is observed through the coefficients estimated for dummy variables assigned to reserve or grand reserve categories. Since the base category is standard, the results suggest that higher categories of Douro wine perform worse in the international market (in value, $-36 \%$ for reserve and $-78 \%$ for grand reserve, and, in volume, $-45 \%$ for reserve and $-81 \%$ for grand reserve). An explanation for this phenomenon could be the difficulty of these markets in interpreting the differences in quality for Portuguese wines and, in particular, Douro wines.

In order to determine whether the quality differences of Douro wine are homogeneously assimilated by international markets, nine world regions are distinguished through dummy variables in the next estimations. This categorization is based on the World Bank's list of economies: West Europe, Anglo-Saxon (AS) outside Europe, Latin America and Caribbean (LAC), East Asia and Pacific with high income (EAP-HI), East Asia and Pacific excluding high income countries (EAP ex. HI), East Europe and Central Asia (EECA), Sub-Saharan Africa (SSA), Middle East and North Africa (MENA) and South Asia (SA). Additionally, to simplify the analysis of the disparity in assimilation of quality differences of Douro wines among these regions, only two categories are considered in Tables 3 and 4: standard and an aggregate of reserve and grand reserve (R/GR). In West Europe (the control category) the influence of a reserve or grand reserve classification on exports of wines is the estimated coefficient of $\mathrm{R} / \mathrm{GR}$, whilst for other regions it is necessary to sum the coefficient of R/GR with the coefficient of the relative interaction.

\footnotetext{
${ }^{9}$ In fact, Portuguese wine represents almost all of Angola wine imports.
} 


\begin{tabular}{|c|c|c|}
\hline & (5) & (6) \\
\hline VARIABLES & Value $(€)$ & Volume $(€)$ \\
\hline \multirow[t]{2}{*}{ GDPpc (ln) } & $1.581 * * *$ & $1.374 * * *$ \\
\hline & $(0.175)$ & $(0.155)$ \\
\hline \multirow[t]{2}{*}{ Distance } & -0.867 & -0.835 \\
\hline & $(0.587)$ & $(0.536)$ \\
\hline \multirow[t]{2}{*}{ Common language } & $5.660 * * *$ & $4.933 * * *$ \\
\hline & $(0.746)$ & $(0.682)$ \\
\hline \multirow[t]{2}{*}{ Common currency } & $2.867 * *$ & $2.412 * *$ \\
\hline & $(1.121)$ & $(1.056)$ \\
\hline \multirow[t]{2}{*}{ RTA } & -0.236 & -0.270 \\
\hline & $(0.762)$ & $(0.643)$ \\
\hline \multirow[t]{2}{*}{ Contiguity } & -5.056 & -5.007 \\
\hline & $(4.328)$ & $(4.023)$ \\
\hline \multirow[t]{2}{*}{$\mathrm{R} / \mathrm{GR}$} & $1.190^{* *}$ & 0.567 \\
\hline & $(0.538)$ & $(0.466)$ \\
\hline \multirow[t]{2}{*}{$\mathrm{R} / \mathrm{GR} * \mathrm{AS}$} & $4.752 * * *$ & $4.220 * * *$ \\
\hline & $(1.233)$ & (1.209) \\
\hline \multirow[t]{2}{*}{$\mathrm{R} / \mathrm{GR} * \mathrm{LAC}$} & $-1.896^{* *}$ & $-1.515^{* *}$ \\
\hline & $(0.775)$ & $(0.651)$ \\
\hline \multirow[t]{2}{*}{ R/GR*EAP-HI } & 0.265 & 0.252 \\
\hline & $(1.705)$ & $(1.425)$ \\
\hline \multirow[t]{2}{*}{ R/GR*EAP ex. HI } & -1.148 & -0.671 \\
\hline & $(0.723)$ & $(0.619)$ \\
\hline \multirow[t]{2}{*}{ R/GR*EECA } & $-2.939 * * *$ & $-2.364 * * *$ \\
\hline & $(0.884)$ & $(0.731)$ \\
\hline \multirow[t]{2}{*}{$\mathrm{R} / \mathrm{GR} * \mathrm{SSA}$} & -0.883 & -0.438 \\
\hline & $(0.709)$ & $(0.604)$ \\
\hline \multirow[t]{2}{*}{ R/GR*MENA } & $-4.336 * * *$ & $-3.494 * * *$ \\
\hline & $(0.883)$ & $(0.732)$ \\
\hline \multirow[t]{2}{*}{$\mathrm{R} / \mathrm{GR} * \mathrm{SA}$} & $-2.129 * *$ & $-1.471 * *$ \\
\hline & $(0.821)$ & $(0.720)$ \\
\hline \multirow[t]{2}{*}{ Time effects' significance } & $1.95 * *$ & 1.62 \\
\hline & {$[0.047]$} & {$[0.111]$} \\
\hline Observations & 3,726 & 3,726 \\
\hline R-squared & 0.501 & 0.502 \\
\hline
\end{tabular}

Notes: Standard errors in parentheses; $* * * \mathrm{p}<0.01, * * \mathrm{p}<0.05, *$ $\mathrm{p}<0.1$; Figures in [ ] indicate p-values; The categorization for world regions follows World Bank list of economies, except for three new regions proposed by Agostino and Trivieri (2014): Anglo-Saxon outside Europe (Australia, Canada, New Zealand and USA), East Asia and Pacific with high income (Hong Kong, Japan, Korea Rep., Macao and Singapore) and West Europe (Austria, Belgium, Croatia, Cyprus, the Czech Republic, Denmark, Estonia, Finland, France, Germany, Greece, Greenland, Hungary, Iceland, Ireland, Italy, Luxembourg, Malta, the Netherlands,

Norway, Poland, San Marino, Slovak Republic, Slovenia, Spain, Sweden, Switzerland, United Kingdom).

Source: Author's computation

Table 3: BVOLS estimations of export determinants of Douro wine and the disparity in assimilation of its quality differences among world regions, 2006-2015.

The results in Table 4 suggest that quality differences of Douro wine are not homogeneously interpreted across world regions. Anglo-Saxon and West European countries are the world regions where the quality of Douro wine is a greater influence on exports. On the other hand, it is possible to observe that the negative influence of quality estimated in Table 2 is mainly due to two regions: Middle East and North Africa, and East Europe and Central Asia. These results show that these two markets do not differentiate the quality of Douro wine.

\begin{tabular}{lcc}
\hline & $(5)$ & $(6)$ \\
VARIABLES & Value $(€)$ & Volume $(€)$ \\
\hline $\begin{array}{l}\text { Anglo-Saxon (outside Europe): R/GR + R/ } \\
\text { GR*AS }\end{array}$ & $5.943^{* * *}$ & $4.786^{* * *}$ \\
& $(1.130)$ & $(1.128)$ \\
Latin America and Caribbean: R/GR + R/ & -0.706 & $-0.948^{* *}$ \\
GR*LAC & $(0.486)$ & $(0.389)$ \\
& 1.455 & 0.819 \\
$\begin{array}{l}\text { East Asia and Pacific with high income: R/GR } \\
+ \text { R/GR*EAP-HI }\end{array}$ & $(1.607)$ & $(1.340)$ \\
& 0.042 & -0.105 \\
$\begin{array}{l}\text { East Asia and Pacific excl. high income: R/GR } \\
+ \text { R/GR*EAP ex. HI }\end{array}$ & $(0.522)$ & $(0.449)$ \\
& $-1.748^{* * *}$ & $-1.797^{* * *}$ \\
$\begin{array}{l}\text { East Europe and Central Asia: R/GR + R/ } \\
\text { GR*EECA }\end{array}$ & $(0.577)$ & $(0.461)$ \\
& 0.307 & 0.129 \\
South Asia: R/GR + R/GR*SA & $(0.368)$ & $(0.306)$ \\
$\begin{array}{l}\text { Middle East and North Africa: R/GR + R/ } \\
\text { GR*MENA }\end{array}$ & $-3.145^{* * *}$ & $-2.927^{* * *}$ \\
& $(0.621)$ & $(0.508)$ \\
& -0.939 & -0.904 \\
& $(0.642)$ & $(0.574)$ \\
\hline
\end{tabular}

Notes: Standard errors in parentheses; The standard errors are calculated using the formula

$\tilde{\sigma}=\sqrt{\operatorname{var}\left(\tilde{\beta}_{R / G R}\right)+\operatorname{var}\left(\tilde{\beta}_{\text {interaction }}\right)+2 \operatorname{cov}\left(\tilde{\beta}_{R / G R} * \tilde{\beta}_{\text {interaction }}\right)} ;$

$* * * \mathrm{p}<0.01, * * \mathrm{p}<0.05, * \mathrm{p}<0.1$.

Source: Author's computation

Table 4: Influence of quality on Douro wine exports by world regions, 2006-2015.

\section{Conclusion}

Vertical differentiation is of fundamental importance for a large number of products, of which wine is a typical case. For that reason this study considers the performance of three different categories of Douro wine in international trade over time and world regions. To accomplish this, a gravity model considering 192 of Portugal's trading partners between 2006 and 2015 is estimated using the BVOLS estimator.

The results of this study suggest that only some 
world regions reward quality when they choose between distinct categories of Douro wines. West Europe and Anglo-Saxon countries (outside Europe) are two world regions associated with significant value premiums for reserve and grand reserve categories of Douro wine. However, the Middle East and North Africa, and East Europe and Central Asia are two world regions where the value premium is associated to the standard category, illustrating the difficulties of Douro wine in imposing quality differentiation in some markets.

The robustness of the empirical results is enhanced by taking vertical differentiation into consideration, thereby providing accurate information that should be noted both by policymakers in designing effective trade policies, and by managers whose intention is to promote products in line with international market trends. This is especially true for the wine industry.

For future research, it would be fruitful to extend this analysis to other industries characterised by both vertical and horizontal differentiation. Moreover, the use of longer time series - currently not available for Douro wine - in such analyses would allow macroeconomic shocks to be studied.

\section{Acknowledgements}

This work is supported by the project NORTE -01-0145-FEDER-000038 (INNOVINE \& WINE - Innovation Platform of Vine \& Wine) and national funds, through the FCT - Portuguese Foundation for Science and Technology under the project UID/SOC/04011/2019.

Corresponding authors

Anthony Macedo

Department of Economics, Sociology and Management, Centre for Transdisciplinary Development Studies University of Trás-os-Montes and Alto Douro, Quinta de Prados, 5001-801 Vila Real, Portugal

E-mail: anthonym@utad.pt

\section{References}

[1] Agostino, M. and Trivieri, F. (2014) "Geographical indication and wine exports. An empirical investigation considering the major European producers", Food Policy, Vol. 46, pp. 22-36. ISSN 0306-9192. DOI 10.1016/j.foodpol.2014.02.002.

[2] Agostino, M. and Trivieri, F. (2016) "European wines exports towards emerging markets. The role of geographical identity", Journal of Industry, Competition and Trade, Vol. 16, pp. 233-256. ISSN 1573-7012. DOI 10.1007/s10842-015-0210-z.

[3] Alchian, A. A. and Allen, W. R. (1972) “University economics: Elements of inquiry”, Belmont CA, Wadsworth. ISBN 0534000304.

[4] Anderson, J. E. (1979) "A theoretical foundation for the gravity equation", The American Economic Review, Vol. 69, No. 1, pp. 106-116. ISSN 0002-8282.

[5] Anderson, J. E. and van Wincoop, E. (2003) "Gravity with gravitas: A solution to the border puzzle", The American Economic Review, Vol. 93, No. 1, pp. 170-192. ISSN 0002-8282. DOI 10.1257/000282803321455214.

[6] Balogh, J. M. and Jámbor, A. (2018) "The role of culture, language and trade agreements in global wine trade", AGRIS on-line Papers in Economics and Informatics, Vol. 10, No. 3, pp. 17-29. ISSN 1804-1930. DOI 10.7160/aol.2018.100302.

[7] Baier, S. L. and Bergstrand, J. H. (2009) "Bonus vetus OLS: a simple method for approximating international trade-cost effects using the gravity equation", Journal of International Economics, Vol. 77, pp. 77-85. ISSN 0022-1996. DOI 10.1016/j.jinteco.2008.10.004.

[8] Bergstrand, J. H. (1985) "The gravity equation in international trade: some microeconomic foundations and empirical evidence", The Review of Economics and Statistics, Vol. 67, No. 3, pp. 474-481. E-ISSN 15309142, ISSN 00346535. DOI 10.2307/1925976. 
[9] Bergstrand, J. H. (1989) "The generalized gravity equation, monopolistic competition, and factor proportions theory in international trade", The Review of Economics and Statistics, Vol. 71, No. 1, pp. 143-153. ISSN 00346535. DOI 10.2307/1928061.

[10] Boccard, N. (2010) "Industrial organization: A contract-based approach", Girona, Univ. of Girona. ISBN 84-609-9337-X.

[11] Brentari, E., Levaggi, R. and Zuccolotto, P. (2011) "Pricing strategies for Italian red wine", Food Quality and Preference, Vol. 22, pp. 725-732. ISSN 0950-3293.DOI 10.1016/j.foodqual.2011.06.001.

[12] Cardebat, J. and Figuet, J. (2004) “What explains Bordeaux wine prices?", Applied Economics Letters, Vol. 11, pp. 293-296. ISSN 1350-4851. DOI 10.1080/1350485042000221544.

[13] Castillo, J. S., Villanueva, E. C. and García-Cortijo, M. C. (2016) "The international wine trade and its new export dynamics (1988-2012): A gravity model approach", Agribusiness, Vol. 32, No. 4, pp. 466-481. DOI 10.1002/agr.21463.

[14] Church, J. and Ware, R. (2000) "Industrial Organization: A Strategic Approach", New York NY, Irwin McGraw Hill. ISBN 0-256-20571-X.

[15] Crozet, M., Head, K. and Mayer, T. (2012) "Quality sorting and trade: firm-level evidence for French wine", The Review of Economic Studies, Vol. 79, No. 2, pp. 609-644. E-ISSN 1467-937X, ISSN 0034-6527 DOI 10.1093/restud/rdr030.

[16] Dal Bianco, A., Boatto, V. L., Caracciolo, F. and Santeramo, F. G. (2016) "Tariffs and non-tariff frictions in the world wine trade", European Review of Agricultural Economics, Vol. 43, No. 1, pp. 31-57. ISSN 0165-1587. DOI 10.1093/erae/jbv008.

[17] Dal Bianco, A., Estrella-Orrego, M. J., Boatto, V. L. and Gennari, A. J. (2017) "Is Mercosur promoting trade? Insights from Argentinean wine exports", Spanish Journal of Agricultural Research, Vol. 15, No. 1. E-ISSN 2171-9292. DOI 10.5424/sjar/2017151-9270.

[18] Dascal, D., Mattas, K. and Tzouvelekas, V. (2002) "An analysis of EU wine trade: A gravity model approach", International Advances in Economic Research, Vol. 8, No. 2, pp. 135-147. ISSN 1083-0898. DOI 10.1007/bf02295344.

[19] Eaton, J. and Kortum, S. (2002) “Technology, geography, and trade”, Econometrica, Vol. 70, No. 5, pp. 1741-1779. ISSN 1468-0262. DOI 10.1111/1468-0262.00352.

[20] Gouveia, S. and Macedo, A. (2017) "Principais mercados de destino dos vinhos do Porto e Douro", In: Rumo estratégico para o setor dos vinhos do Porto e Douro, Relatório Final - Estudo de Base, Porto, IVDP/UTAD, pp. 172-212.

[21] Gouveia, S., Rebelo, J. and Lourenço-Gomes, L. (2018) "Port wine exports: A gravity model approach", International Journal of Wine Business Research, Vol. 30, No. 2, pp. 218-242. ISSN 1751-1062. DOI 10.1108/IJWBR-02-2017-0008.

[22] Helpman, E. (1984) "Increasing returns, imperfect markets, and trade theory", In: Jones R. W. and Kenen P. B. (eds): Handbook of international economics, Amsterdam, North-Holland, pp. 325-365. DOI 10.1016/S1573-4404(84)01010-8.

[23] Helpman, E. (1987) "Imperfect competition and international trade: Evidence from fourteen industrial countries", Journal of the Japanese and International Economies, Vol. 1, No. 1, pp. 62-81. ISSN 0889-1583. DOI 10.1016/0889-1583(87)90027-X.

[24] Helpman, E. and Krugman, P. R. (1985) "Market structure and foreign trade; increasing returns, imperfect competition and the international economy", Cambridge, MIT Press. ISBN 9780262580878.

[25] Hummels, D. and Klenow, P. J. (2005) "The variety and quality of a nation's exports", American Economic Review, Vol. 95, No. 3, pp. 704-723. E-ISSN 1944-7981. ISSN 0002-8282. DOI $10.1257 / 0002828054201396$. 
[26] Hummels, D. and Skiba, A. (2004) "Shipping the good apples out? An empirical confirmation of the Alchian-Allen conjecture", Journal of Political Economy, Vol. 112, No.6, pp. 1384-1402. E-ISSN 1537534X, ISSN 00223808. DOI 10.1086/422562.

[27] Khandelwal, A. (2010) "The long and short (of) quality ladders", The Review of Economic Studies, Vol. 77, No. 4, pp. 1450-1476. E-ISSN 1467-937X, ISSN 0034-6527. DOI 10.1111/j.1467-937X.2010.00602.x.

[28] Linder, S. B. (1961) “An essay on trade and transformations", Stockholm, Almqvist \& Wiksell, New York NY, Wiley and Sons.

[29] Lombardi, P., Dal Bianco, A., Freda, R., Caracciolo, F. and Cembalo, L. (2016) "Development and trade competitiveness of the European wine sector: A gravity analysis of intra-EU flows", Wine Economics and Policy, Vol. 5, No. 2, pp. 50-59. ISSN 2212-9774. DOI 10.1016/j.wep.2015.12.002.

[30] Manova, K. and Zhang, Z. (2012) "Export prices across firms and destinations", The Quarterly Journal of Economics, Vol. 127, No. 1, pp. 379-436. E-ISSN 1531-4650, ISSN 0033-5533. DOI 10.1093/qje/qjr051.

[31] Melitz, M. J. (2003) "The impact of trade on intra-industry reallocations and aggregate industry productivity", Econometrica, Vol. 71, No. 6, pp. 1695-1725. E-ISSN 1468-0262. DOI 10.1111/1468-0262.00467.

[32] Olper, A., Curzi, D., Frisio, D. and Raimondi, V. (2012) "Home bias in consumption: a comparison between wine and beer", German Journal of Agricultural Economics, Vol. 61, No. 4, pp. 223-234. ISSN 00021121.

[33] Pomarici, E. (2016) "Recent trends in the international wine market and arising research questions", Wine Economics and Policy, Vol. 5, No. 1, pp. 1-3. ISSN 2212-9774. DOI 10.1016/j.wep.2016.06.001.

[34] Rebelo, J. and Muhr, D. (2012) "Innovation in wine SMEs: the Douro Boys informal network", Studies in Agricultural Economics, Vol. 114, pp. 1-15. E-ISSN 2063-0476, ISSN 1418-2106. DOI $10.7896 / j .1118$.

[35] Schamel, G. (2006) "Geography versus brands in a global wine market", Agribusiness, Vol. 22, No. 3, pp. 363-374. E-ISSN 1520-6297. DOI 10.1002/agr.20091.

[36] Schott, P. K. (2004) "Across-product versus within-product specialization in international trade", The Quarterly Journal of Economics, Vol. 119, No. 2, pp. 647-678. E-ISSN 1531-4650, ISSN 0033-5533. DOI 10.1162/0033553041382201.

[37] Silva J. S. and Tenreyro, S. (2006) "The log of gravity", The Review of Economics and Statistics, Vol. 88, pp. 641-658. ISSN 00346535. DOI 10.1162/rest.88.4.641.

[38] Tinbergen, J. (1962) "An Analysis of World Trade Flows", In: "Shaping the World Economy", New York NY, Twentieth Century Fund, Vol. 5, No. 1, pp. 27-30.

[39] Verhoogen, E. A. (2008) "Trade, quality upgrading, and wage inequality in the Mexican manufacturing sector", The Quarterly Journal of Economics, Vol. 123, No. 2, pp. 489-530. E-ISSN 1531-4650, ISSN 0033-5533. DOI 10.1162/qjec.2008.123.2.489. 


\section{Appendix}

\begin{tabular}{lrrrrrr}
\hline Variables & Obs. & Mean & Med. & Std. Dev. & Min & Max \\
\hline exports (euro) & 5589 & 59678.7 & 0.0 & 293215.1 & 0.0 & 5977109.0 \\
Standard & 1863 & 109569.5 & 0.0 & 451585.7 & 0.0 & 5977109.0 \\
Reserve & 1863 & 54020.3 & 0.0 & 213610.3 & 0.0 & 2156674.0 \\
Grand reserve & 1863 & 15446.4 & 0.0 & 63075.8 & 0.0 & 663436.0 \\
exports (litres) & 5589 & 14823.9 & 0.0 & 84157.4 & 0.0 & 1637610.0 \\
Standard & 1863 & 33385.1 & 0.0 & 138287.0 & 0.0 & 1637610.0 \\
Reserve & 1863 & 9719.9 & 0.0 & 39380.5 & 0.0 & 608127.0 \\
Grand reserve & 1863 & 1366.7 & 0.0 & 5377.2 & 0.0 & 59222.0 \\
gdppc (euro) & 5589 & 10449.0 & 3659.9 & 14960.2 & 124.8 & 91887.9 \\
dist (km) & 5589 & 6503.1 & 5926.0 & 3918.6 & 680.0 & 19539.0 \\
lang & 5589 & 0.0 & 0.0 & & 0.0 & 1.0 \\
curr & 5589 & 0.1 & 0.0 & & 0.0 & 1.0 \\
rta & 5589 & 0.3 & 0.0 & & 0.0 & 1.0 \\
cont & 5589 & 0.0 & 0.0 & & 0.0 & 1.0 \\
\hline
\end{tabular}

Notes: For the binary variables lang, curr, rta and cont the mean represents the percentage of observations equal to one Source: Authors' computation

Table A1: Descriptive statistics.
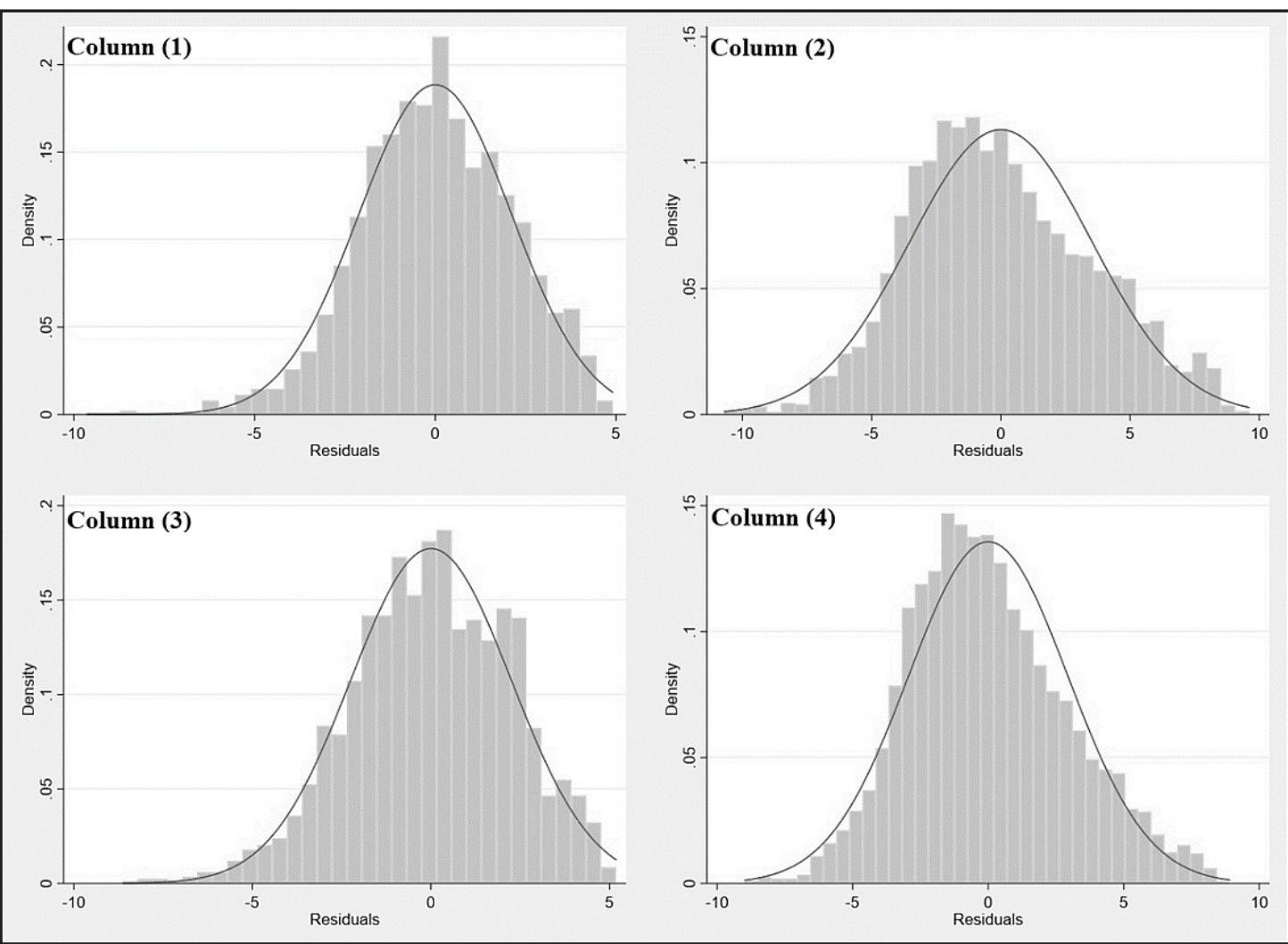

Source: Authors' computation

Figure A1: Distribution of the residuals of BVOLS estimations of export determinants of Douro wine. 